\title{
EVALUASI PENGAJARAN GURU BAHASA ARAB DI MAN III RAWASARI JAKARTA PUSAT
}

\author{
Siti Jubaidah* \\ *Dosen Tetap Jurusan Bahasa dan Sastra Arab FBS UNJ \\ Email : jubaidahsiti@gmail.com
}

\begin{abstract}
Teacher's self evaluation is a way to guide teachers in identifying strengths and weaknesses in learning. Improving teacher's professionalism started by recognizing and realizing the weaknesses in learning, and by a willingness to enhance self competence. This article is a result of a research that examined four domains that affect students achievement, namely the strategies and teacher's behavior in learning, planning and preparation done before learning, reflection on learning, and collegiality that supported teacher professionalism.

This study aims at describing the strengths and weaknesses of teacher's in Arabic learning process, and describing the need for teachers to increase professionalism in teaching. The data was obtained by an instrument in form of a questionnaire of teacher's self evaluation. Respondents consisted of Arabic teacher senior high school of the MAN 3 Rawasari. The instrument used has been validated.

The result showed that most of the teachers carried out most of the components contained in the strategies and teaching behaviors and implemented teaching planning and preparation. In teaching planning and in learning process, however, teacher colleagues were still rarely involved for professional development. Reflection on the learning process and planning is rarely conducted jointly with colleagues. For further improvement of teacher learning, more intensive discussion with colleagues, principals, and supervisors are required. Besides, teachers can observe teaching process of other teachers, obtain feedback on learning not only from colleagues but also from principals and supervisors, and coaching done by the principal or learning expert.
\end{abstract}

Keywords: self-evaluation, teaching, improvement, professionalism, strengths, weaknesses, high school's teacher. 


\section{PENDAHULUAN}

Keberhasilan sebuah pembelajaran dapat dilihat dari prestasi yang diraih pembelajar. Nilai-nilai akademik yang dicapai oleh siswa melaui proses pembelajaran merupakan produk yang menjadi ukuran mutu di dunia pendidikan. Djemari Mardapi menguraikan bahwa perkembangan kualitas pendidikan dari tahun ke tahun tidak berubah, walau berfluktuasi namun masih dalam ketegori rendah. Analisis hasil evaluasi pendidikan yang bersifat nasional untuk memperoleh informasi yang akurat tentang perbaikan kualitas pendidikan belum banyak dilakukan, sehingga tiap sekolah tidak menerima informasi tentang kekurangannya secara rinci. Akibatnya proses pembelajaran yang dilakukan di kelas dari tahun ke tahun tidak banyak mengalami perubahan.

Banyak faktor yang menentukan keberhasilan sebuah pembelajaran dan berfungsi saling melengkapi dan mendukung. Guru sebagai ujung tombak pembelajaran dapat bekerja secara maksimal apabila didukung oleh faktor internal dan eksternal. Dari banyak peneiltian yang dilakukan Darling-Hammond (2010), secara umum guru yang efektif memiliki karakteristik sebagai berikut: (1) inteleligensi yang secara umum tinggi, dan kemampuan verbal yang membantu mereka menyusun dan menjelaskan ide-ide, dan kemampuan mengamati dan berfikir diagnostik; (2) pengetahuan yang mendalam terhadap isi materi di bidang yang mereka ajarkan; (3) pengetahuan tentang bagaimana mengajarkan bidang tersebut kepada orang lain (pengetahuan pedagogis), khususnya bagaimana mengembangkan ketrampilan berfikir tingkat tinggi; (4)pemahaman tentang pembelajar dan cara mereka belajar dan perkembangan - termasuk bagaimana menilai dan menjembatani belajar, bagaimana mendorong siswa yang memiliki perbedaan belajar atau kesulitan, dan bagaimana mendorong belajar bahasa dan isi bagi mereka yang tidak memiliki kecakapan dalam bahasa pengajaran; (5) kepakaran yang adaftif yang memungkinkan mereka membuat keputusan tentang apa yang mungkin dilakukan dalam konteks yang dihadapi dalam merespon kebutuhan siswa.

Gurney (2007) menguraikan ada lima faktor kunci yang memberikan dasar untuk pengajaran yang baik, yaitu: (1) pengetahuan guru, antusiasme dan tanggung jawab untuk belajar, (2) aktivitas kelas yang mendorong belajar, (3) aktivitas penilaian yang mendorong belajar melalui pengalaman, (4) umpan balik yang efektif yang membentuk proses belajar di kelas, dan (5) interaksi yang efektif antara guru dan siswa, menciptakan lingkungan yang menghormati, mendorong dan menstimulasi belajar melalui pengalaman. Menurut Sato Masaaki (2012: 21) faktor yang menentukan mutu pembelajaran adalah: (1) kualitas tugas yang diberikan kepada siswa atau Rencana Pelaksanaan Pembelajaran (RPP), (2) belajar dalam hubungan yang terjalin (dialog dan kolaborasi), dan (3) keaktifan, semangat, kognisi dan emosi siswa. Menurut pengamatan Sato Masaaki (2012: 22) tidak jarang guru di Indonesia menyuruh siswa agar merekamenyalin apa yang ada di buku pelajaran ke dalam lembar kerja siswa (LKS). Pembelajaran yang demikian tidak layak disebut pembelajaran bermutu tinggi. Untuk memperbaiki masalah tersebut, Anderson \& Kumari (2009) mengusulkan cara untuk mencapai tujuan akhir pembelajaran, yakni hasil belajar siswa, adalah melalui investasi yang berkelanjutan dalam pengembangan pengetahuan dan keterampilan guru kelas dan personalia yang memberikan kepemimpinan pembelajaran.

Evaluasi merupakan aktivitas yang sangat penting dilakukan oleh sebuah institusi atau individu untuk mengetahui keberhasilan terhadap pencapaian sebuah tujuan. Informasi yang diperoleh dari hasil evaluasi dapat digunakan untuk mengidentifikasi kelebihan, kelemahan, dan peluang untuk meningkatkan hasil menjadi lebih baik. Di samping itu, hasil evaluasi dapat digunakan untuk merekomendasikam kebijakan lebih lanjut, apakah program harus dilanjutkan, ditingkatkan, diperluas, atau dihentikan. Pada sebuah program yang baru 
dilaksanakan hasil evaluasi dapat digunakan untuk melihat kebermanfaatan program, sehigga langkah perkembangan selanjutnya dapat ditentukan. Efektivitas dan efisiensi sebuah program dapat diketahui pula melalui evaluasi. Evaluasi dapat dilakukan sebelum, selama, dan atau setelah program selesai dilaksanakan.

Adapun tujuan penelitian ini adalah: (1) mendeskripsikan kelebihan dan kelemahan guru dalam proses pembelajaran, dan (2) mendeskripsikan kebutuhan guru dalam meningkatkan profesionalismenya dalam pembelajaran. Komponen-komponen evaluasi yang digunakan merupakan hasil modifikasi dari evaluasi yang dikemukakan oleh Marzano, Frontier \& Livingston (2011). Penentuan ini didasarkan pada beberapa pertimbangan, antara lain: (1) evaluasi pembelajaran yang tercantum di dalam Permennegpan \& RB No. 16 Tahun 2009 mencakup perencanaan pembelajaran, pelakasanaan pembelajaran, dan penilaian pembelajaran, sedangkan peran kolega dalam meningkatkan profesionalisme pembelajaran belum tercakup di dalam evaluasi; (2) elemen-elemen yang tercakup di dalam masing-masing ranah pada model yang diusulkan Marzano dkk. dapat menjadi elemen-elemen penjabaran dari indikatorindikator kinerja yang terdapat di dalam instrumen PKG; (3)orientasi evaluasi adalah pada proses pembelajaran yang dilakukan oleh guru dan diarahkan pada upaya yang dilakukan guru itu sendiri; (4) dengan bantuan elemen-elemen yang diadaptasi dari model Marzano dkk, evaluasi diri ini dapat membantu guru mengenali masalah pembelajaran secara rinci; dan (5) menentukan rencana perbaikan berdasarkan elemen-elemen yang telah dikenali.

\section{Evaluasi Diri}

Evaluasi diri guru adalah proses dimana guru membuat keputusan tentang kecukupan dan keefektifan pengetahuan, kinerja, kepercayaan, dan pengaruh bagi tujuan perbaikan diri mereka sendiri (Freddano \& Siri, 2012: 1143). Di dalam evaluasi diri, guru sendiri yang mengidentifikasi, menginterpretasi, dan memutuskan informasi terhadap praktik pembelajaran yang telah dilakukan.Kerangka kriteria, standar untuk memutuskan kecukupan terhadap keyakinannya, pengetahuannya, keterampilannya, keefektifannya dibuat oleh guru sendiri. Pada akhirnya guru pula yang memutuskan karakteristik aktivitas pengembangan profesi yang akan dilakukannya sebagai tindak lanjut dari evaluasi diri.

Imai (2008: 48-49; 1998: 27) menjelaskan bahwa titik awal untuk perbaikan adalah mengenali kebutuhan. Hal ini muncul dari pengenalan masalah. Jika tidak ada masalah yang diketahui, tidak ada pengakuan tentang perlunya perbaikan. Sekali menyadari masalah tersebut, kita telah setengah jalan menuju sukses. Mengenali masalah dalam proses pembelajaran tidak mudah, karena guru bekerja di dalam kelas bersama siswa tanpa ada yang memberi umpan balik. Untuk dapat mengenali masalah diperlukan instrumen yang memuat elemen-elemen proses pembelajaran di kelas sehingga dapat membantu guru mengidentifikasi permasalahan yang muncul. Menurut Liker \& Hoseus (2008: xxix) tanpa alat-alat pada tingkat proses, masalah tidak akan terlihat, menjadikan orang-orang enggan untuk mengembangkan kemampuan mereka dalam berfikir dan menemukan masalah.

Melalui evaluasi diri, guru dipandu untuk mengenali kelebihan dan kelemahannya, sehingga dia dapat mengenali kebutuhan demi peningkatan profesionalitasnya. Untuk dapat mengenali kebutuhan tersebut, evaluasi diri guru harus didasari oleh keyakinan bahwa: (1) guru memerlukan kesempatan untuk bertumbuh terkait profesinya, (2) guru menginginkan perbaikan praktik pengajaran dan pengetahuannya; dan (3) guru menginginkan dan memerlukan informasi tentang pengetahuannya, kinerjanya, dan keefektifannya. Tanpa dilandasi oleh keyakinan tersebut, evaluasi diri dapat menghasilkan informasi yang tidak bermanfaat bagi perbaikan dan peningkatan 
profesi karena guru memberikan informasi yang tidak sesuai dengan kondisi yang sebenarnya.

Evaluasi diri guru terhadap pembelajaran dapat dilakukan melaui tugastugas yang dikerjakan oleh siswa, seperti yang dilakukan oleh Deming (1994: 145). Menurutnya tugas-tugas yang dikerjakan oleh siswa dibacanya, bukan untuk diberinya nilai, melainkan sebagai bahan evaluasi diri apa saja yang telah ia lakukan sebagai guru; mengapa ia tidak berhasil dan bagaimana ia memperbaiki pembelajarannya; untuk menemukan apakah ada siswa yang memerlukan bantuan khusus, dan untuk memantau apakah siswa mendapat bantuan; untuk menemukan apakah ada siswa yang melakukan persiapan dengan baik dan layak menerima penghargaan dari kerja kerasnya. Evaluasi diri menjadi wadah bagi guru untuk memikirkan kembali tentang pengajaran yang sudah dilakukan dan mengidentifikasi semua yang telah dicapai: aktivitas apa saja yang sudah tercapai, dan sebagainya. Evaluasi diri adalah saatnya bagi guru untuk merencanakan tanggung jawab baru yang akan dilakukan, menetapkan tujuan yang akan dicapai pada waktu yang akan datang, dan bidang keahlian yang akan ditingkatkan.

\section{Evaluasi Pembelajaran}

Marzano, Frontier, \& Livingston (2011) mengelompokkan evaluasi pembelajaran ke dalam empat ranah, yakni: (1) strategi dan perilaku kelas, (2) perencanaan dan persiapan, (3) refleksi pengajaran, dan (4) kolegialitas dan profesionalisme guru. Tekanan utama di dalam Model Marzano dkk adalah apa yang terjadi di dalam kelas, yakni penggunaan strategi dan perilaku guru untuk meningkatkan prestasi siswa. Tekanan ini membedakan model ini dari model evaluasi guru lainnya. Ranah strategi dan perilaku di kelas berhubungan langsung dengan apa yang dilakukan guru di dalam kelas.

\section{a. Ranah strategi dan perilaku kelas}

Ranah strategi dan perilaku kelas terkait erat dengan apa yang dilakukan guru di dalam kelas dan mempunyai pengaruh langsung terhadap prestasi siswa. Segmen pertama adalah aktivitas rutin dalam pelajaran yang memuat komponen (1) tujuan belajar dan umpan balik, dan (2) aturan dari prosedur. Pada segmen kedua, yaitu tentang isi materi, komponen yang tercakup di dalamnya adalah: (1) interaksi dengan materi baru, (2) praktik dan pendalaman pengetahuan, dan (3) penerapan dan pengujian pengetahuan. Segmen ketiga tentang perilaku yang menyertai memuat komponen: (1) melibatkan siswa, (2) kepatuhan terhadap aturan dan prosedur, (3) hubungan guru/siswa, dan (4) ekspektasi yang tinggi.

\section{b. Ranah perencanaan dan persiapan}

Proses pembelajaran dapat dilakukan secara optimal apabila direncanakan dan dipersiapkan secara matang. Pencapaian prestasi siswa yang tinggi sebagai tujuan pembelajaran ditentukan oleh perencanaan dan persiapan yang efektif. Ranah perencanaan dan persiapan mencakup tiga segmen, yakni: (1) perencanaan dan persiapan untuk meteri pelajaran dan sub materi, (2) perencanaan dan persiapan untuk pemanfaatan bahan/ media pembelajaran, dan (3) perencanaan dan persiapan untuk memenuhi kebutuhan khusus siswa.

\section{c. Ranah refleksi pengajaran}

Ranah refleksi pengajaran menggambarkan kepedulian guru terhadap praktik pengajarannya dan kemampuan mereka dalam menerjemahkan kepedulian diri ke dalam rencana perkembangan profesi yang dipantau dan diputuskan secara layak. Ada dua segmen yang tercakup dalam ranah ini, yaitu mengevaluasi kinerja individu, dan mengembangkan dan menerapkan rencana kemajuan profesi.

\section{d. Ranah kolegialitas dan profesionalisme}

Walaupun ranah kolegialitas dan profesionalisme tidak secara langsung berhubungan dengan pencapaian prestasi belajar siswa, namun ranah ini memberikan suasana yang efektif untuk implementasi ranah strategi dan perilaku kelas. Kolegialitas dan profesionalisme tidak hanya mendeskripsikan karakteristik sekolah, tetapi 
juga tanggung jawab individu dan administrator.

Danielson (2011) dan Marzano dkk (2011) menjelaskan bahwa peningkatan profesionalisme guru dalam pembelajaran selayaknya memanfaatkan peran kolega secara optimal dalam melakukan aktivitas perencanaan pembelajaran dan pemantauan. Optimalisasi peran kolega dalam musyawarah guru mata pelajaran (MGMP) masih belum tampak di dalam Permendikbud.

Hasil evaluasi atau penilaian pembelajaran dapat digunakan sebagai alat bagi guru atau sekolah untuk melakukan refleksi diri. Menurut Marzano (2011: 46) ada dua aspek yang perlu dicermati guru, yaitu: mengevaluasi kinerja diri, dan mengembangkan serta menerapkan perencanaan perkembangan profesional.

\section{METODE PENELITIAN}

Penelitian ini menggunakan metode deskriptif kuantitatif yang mendeskripsikan proses pembelajaran bahasa Arab di MAN III Rawasari Jakarta Pusat. Responden penelitian ini adalah para guru bahasa Arab di MAN III Rawasari.Data dikumpulkan menggunakan instrumen kuesioner dan pedoman interview.

Lavrakas (2012: 653) menguraikan bahwa kuesioner merupakan instrumen utama untuk mengumpulkan data dalam penelitian survey, dan (Gilham, 2004: 2; Schwab, 2005: 38) salah satu cara memperoleh informasi dari orang (atau menjawab pertanyaan penelitian), biasanya, tetapi tidak selalu, dengan mengajukan pertanyaan-pertanyaan). Di dalam kuesioner, peneliti menentukan pertanyaan-pertanyaan yang diajukan dan rentang jawaban yang diberikan. Sementara itu, responden mempunyai pilihan: ya/tidak, setuju/tidak setuju, memilih satu jawaban dari empat atau lima pilihan, dan seterusnya.

Informasi yang digali dari kuesioner evaluasi diri guru meliputi strategi dan perilaku guru di kelas, perencanaan dan persiapan pembelajaran, refleksi, dan kolegialitas dan profesionalisme. Instrumen evaluasi diri yang digunakan telah divalidasi melalui focus group discussion dan teknik Delphi, serta dua kali ujicoba. Instrumen evaluasi diri memuat 96 butir pernyataan, dengan tiga tipe jawaban, yaitu skala Aiken dan Hage (Miller, 1977: 288) yang menunjukkan frekuensi aktivitas dimulai dari tidak pernah - jarang - kadang-kadang sering sampai selalu, pilihan aktivitas yang teramati dan tidak teramati (Ya - Tidak), dan tipe isian. Dua butir terakhir dari instrumen memuat uraian tentang rencana perbaikan yang akan dilakukan oleh guru terkait ke empat ranah, dan kebutuhan guru untuk mendukung perbaikan. Data hasil evaluasi diri dianalisis menggunakan statistik deskriptif berupa persentase.

Menurut Johnson \& Christensen (2012: 198) wawancara adalah metode pengumpulan data dimana orang yang mewawancara (peneliti atau seseorang yang bekerja untuk peneliti) mengajukan pertanyaan-pertanyaan terhadap partisipan penelitian. Wawancara dilakukan kepada kepala sekolah, ketua unit penjamin mutu sekolah atau pengembang akademik dan evaluasi, dan wakil kepala sekolah bidang kurikulum untuk menggali informasi tentang perencanaan pembelajaran, proses pembelajaran, pelaksanaan penjaminan mutu pembelajaran di sekolah, kelebihan, kelemahan, dan permasalahan yang dihadapi, kehidupan kolegialitas dalam mendukung profesionalisme guru, dan informasi tentang usaha yang telah dilakukan dalam pelaksanaan penjaminan mutu pembelajaran.

\section{HASIL DAN PEMBAHASAN}

\section{a. Strategi dan Perilaku di Kelas}

Evaluasi diri dilakukan untuk menggali kelebihan dan kelemahan guru menurut persepsi diri sendiri terhadap empat ranah. Pada ranah strategi dan perilaku guru di kelas 
informasi yang digali dari guru meliputi penyampaian tujuan belajar dan pemberian apresiasi kepada siswa, pada awal pelajaran, dan penilaian pencapaian hasil belajar, penerapan aturan/tata tertib, strategi yang digunakan ketika memperkenalkan materi baru, praktik, dan pendalaman pengetahuan, penerapan pengetahuan, mengaktifkan siswauntuk terlibat dalam pembelajaran, konsistensi implementasi terhadap aturan dan tata tertib yang telah disepakati, membangun komunikasi dengan siswa, menunjukkan sikap respek terhadap siswa, dan kepuasan belajar.

Dari hasil angket yang disebarkan kepadaorang guru bahasa Arab di MAN III Rawasari dapat diketahui bahwa sebagian besar aspek-aspek yang termasuk ke dalam strategi dan perilaku guru di kelas sudah dilakukan oleh guru, meskipun tidak semua guru melaksanakannya.

Dalam melaksanakan pembelajaran, guru memulai pembelajaran dengan menyampaikan tujuan belajar kepada siswa. Guru selalu menyampaikan tujuan belajarnya, membuat catatan kemajuan siswa dalam belajar dan memetakannya, namun tidak ada seorang guru pun yang membuat kontrak belajar pada awal semester. Pada awal pembelajaran aturan kelas yang merupakan bagian dari rutinitas tidak dirumuskan bersama-sama dengan siswa. Guru juga tidak menata ruang kelas yang memudahkan siswa bergerak, dan tidak menghias kelas bersama siswa agar siswa mudah fokus pada pelajaran.

Untuk mengarahkan siswa dapat berinteraksi dengan materi baru, terdapat beberapa strategi yang dapat dilakukan guru, agar siswa dapat memahami materi baru. Adapun strategi yang digunakan dapat berupa penjelasan tentang kegunaan materi yang akan dibahas pada awal pelajaran, membagi materi ke dalam sub-sub materi agar dapat dengan mudah dicerna oleh siswa, memantau pemahaman siswa melalui aktivitas kerja kelompok,menggiring siswa membuat kesimpulan dan membuat visualisasi materi baru (misalkan berbentuk grafik, gambar, piktograf, flow chart), serta mengajukan pertanyaan. Hasil analisis data menunjukkan bahwa strategi yang selalu dilakukan oleh sebagian besar guru adalah bertanya, sedangkan strategi lainnya jarang bahkan tidak pernah dilakukan.

Strategi lainnya yang perlu dilakukan oleh guru untuk memperdalam atau mempraktikkan pengetahuan siswa terhadap materi yang telah dipelajari adalah membuat kelompok siswa untuk mengerjakan tugas pendalaman materi, memantau cara siswa bekerja di dalam kelompok, memberikan tugas rumah dan memantau penyelesaiannya, menuntun siswa untuk melakukan perbandingan dan mangamati perbedaan, menggali alasan, memberikan tugas proyek dan memantau penyelesaiannya. Strategi ini merupakan strategi yang termasuk ke dalam ranah kognitif tingkat analisis. Namun, penjelasan tentang kegunaan materi yang akan dibahas jarang dilakukan oleh guru . Guru juga jarang membagi siswa ke dalam kelompok kecil untuk mendiskusikan subsub materi baru, tidak memantau kemampuan siswa mengaitkan pengetahuan yang sudah dimiliki dengan yang akan dipelajari, dan memberikan tugas yang menuntut daya analisis siswa. Hasil penelitian menunjukkan bahwa sebagaian besar guru jarang melakukan aktivitas tersebut, bahkan tidak pernah sama sekali.

Di samping strategi yang digunakan untuk pendalaman materi, guru selayaknya mengamati penerapan pengetahuan yang telah diperoleh siswa dalam kehidupan sehari-hari. Namun strategi yang menuntut kemampuan taksonomi Bloom tingkat analisis jarang bahkan tidak pernah dilakukan oleh guru. Strategi seperti ini meminta siswa untuk membuat dugaan dari permasalahan yang terkait dengan pengetahuan yang telah diperolehnya, atau melibatkan siswa dalam tugas-tugas yang kompleks (seperti membuat keputusan, pemecahan masalah, investigasi eksperimental, penyelidikan) yang menuntut mereka menguji dugaan merupakan strategi yang dapat diberikan kepada siswa untuk melatihkan daya analisis siswa dalam mencermati sebuah permasalahan. 
Melibatkan siswa dalam setiap aktivitas pembelajaran di kelas perlu selalu dilakukan oleh guru, karena pembelajaran berlangsung untuk kepentingan siswa. Strategi yang dapat dilakukan guru untuk memotivasi siswa terlibat aktif dalam proses pembelajaran adalah menggunakan metode yang dapat mengaktifkan siswa di kelas, misalnya melalui permainan, debat, cerita unik, dll., memantau fokus siswa pada materi ketika aktivitas tersebut berlangsung dan menilainya. Dalam hal ini guru harus peka ketika semangat belajar siswa menurun.

Untuk mengenali ketaatan atau kekurangtaatan terhadap aturan dan prosedur, guru dituntut untuk: (a) menunjukkan "withiness" (guru menyadari adanya variasi dalam perilaku siswa yang mugkin menunjukkan gangguan yang potensial dan langsung menanganinya), (b) menerapkan konsekuensi untuk pelanggaran terhadap aturan dan prosedur. Sebagian guru mengakui sering memberikan teguran ketika siswa melanggar aturan, dan menerapkan konsekuensi bagi siswa yang indisipiner secara konsisten. Selain penerapan konsekuensi terhadap pelanggaran, guru juga memberikan penghargaan kepada siswa yang taat pada aturan, baik berupa pemberian poin, maupun bentuk penghargaan lainnya. Guru memantau kepekaan siswa terhadap lingkungan di dalam kelas dan menyadari sumber potensial gangguan. Sebagai tindak lanjutnya, gurumenelusuri penyebab keindisiplineran siswa.

Dalam membangun komunikasi dengan siswa, guru merancang aktivitas yang dapat menghubungkan antara materi dan minat pribadi siswa, namun beberapa guru yang melakukan aktivitas tersebut. Hampir semua responden mengakui bahwa mereka jarang membuat humor di dalam pembelajaran, dan jarang tersenyum kepada siswa. Kelas berada di dalam kendali guru sepenuhnya. Di dalam pembelajaran sikap respek yang ditunjukkan oleh guru kepada seluruh siswa dapat memupuk rasa dihargai sebagai siswa. Sebagian besar guru di MAN 3 dapat mengenali siswa yang mempunyai kemampuan akademis rendah dan berupaya menunjukkan perhatian dengan isyarat verbal dan non verbal. Siswa yang memiliki kemampuan akademis rendah mendapat pantauan khusus dari guru agar mereka berpartisipasi dalam pembelajaran. Upaya yang dilakukan oleh guru untuk membantu siswa tersebut antara lain dengan memecah pertanyaan ke dalam pertanyaan-pertanyaan sederhana, memberikan waktu lebih banyak kepada mereka dalam berlatih atau menjawab pertanyaan. Sebagian guru tidak merasa puas dengan prestasi yang sudah dicapai oleh siswa mereka.

\section{b. Perencanaan dan Persiapan}

Proses pembelajaran dapat terlaksana dengan baik apabila direncanakan dan dipersiapkan secara matang. Adapun yang harus direncanakan dan dipersiapkan meliputi isi materi, media, dan kebutuhan spesifik siswa. Dari hasil evaluasi diri guru diperoleh informasi bahwa sebagian besar guru selalu memilih materi yang aktual sesuai kondisi siswa, memilih strategi yang disukai siswa, mempertimbangkan keterkaitan antara materi sebelumnya dan materi baru, menyusun materi ke dalam subsub yang lebih kecil sehingga siswa lebih mudah memahami materi, menyusun indikator sesuai dengan tujuan sehingga siswa dapat mencapai standar kelulusan minimal (SKM). Untuk meningkatkan profesionalisme guru, guru menyusun perencanaan mengajar bersama guru lain sesama bidang studi. Di dalam merencanakan pembelajaran, guru menentukan alat/bahan yang tersedia, dan merancang cara pemanfaatan alat/bahan yang tersedia untuk meningkatkan pemahaman siswa. Aspek perbedaan karakteristik siswa menjadi pertimbanganguru dalam mempersiapkan dan merencanakan pembelajaran. Namun, ratarata guru jarang mempertimbangkan kebutuhan belajar siswa secara individu, dan proses adaptasi materi.

\section{c. Refleksi Pembelajaran}

Ranah ketiga yang menjadi faktor keberhasilan proses pembelajaran adalah evaluasi kinerja diri. Menurut Marzano (2011: 46) ada dua aspek yang perlu dicermati guru, yaitu: mengevaluasi kinerja 
diri dan mengembangkan serta menerapkan perencanaan perkembangan profesional. Dalam melakukan evaluasi diri, guru harus menerjemahkannya ke dalam tindakan yang sistematis. Ada dua aktivitas yang termasuk ke dalam aspek ini, yaitu:(a) mengembangkan rencana pertumbuhan dan perkembangan secara tertulis, dan (b) memonitor kemajuan terhadap perencanaan pertumbuhan profesional.

Hasil evaluasi diri guru bahasa Arab terhadap ranah reflekasi pembelajaran menunjukkan bahwa hampir seluruh responden menanyakan pemahaman siswa terhadap isi materi yang baru mereka pelajari, menyadari kelemahan diri dalam mengajar, bertanya kepada kolega untuk mengatasi kelemahan dalam mengajar, mengidentifikasi penyebab kegagalan mereka mengajar dilihat dari prestasi siswa, menanyakan kepada siswa tentang hal yang kurang menyenangkan pada pembelajaran yang telah mereka ikuti, mengevaluasi efektivitas penyampaian materi pelajaran, meminta masukan dari siswa tentang strategi mengajar yang tidak disuaki ketika pembelajaran berlangsung, dan membuat perubahan strategi mengajar dengan memperhatikan perbedaan siswa secara individu di kelas.Namun, ada beberapaguru memberikan penilaian terhadap pemahaman siswa dengan teknik penilaian yang tidak bervariasi, dan kurang dari separuh guru menyediakan waktu khusus di luar jam pelajaran bagi siswa yang nilainya belum mencapai standar ketuntasan minimal. Lebih dari separuh responden jarang membuat rencana pengembangan profesi dengan target tertentu secara tertulis, jarang membuat catatan kemajuan pengembangan profesi, dan jarang mendiskusikan rencana pengembangan profesi dengan kolega/atasan.

\section{d. Kolegialitas dan Profesionalisme}

Ranah keempat yang secara tidak langsung memiliki peran penting terhadap pencapaian prestasi belajar yang tinggi adalah ranah kolegialitas dan profesionalisme. Ranah ini mewarnai ketiga ranah lainnya. Artinya, pada proses pembelajaran peran kolega sangat besar dalam memberikan informasi terhadap proses pembelajaran yang dilakukan oleh guru, dan melalui pengamatan dari kolega ketika proses pembelajaran berlangsung, seorang guru dapat mengetahui kelebihan dan kekurangannya dalam proses pembelajaran.

Hasil evaluasi dari guru menunjukkan bahwa dalam membangun lingkungan kerja yang positif, guru membina interaksi yang positif dengan kolega, siswa, dan orangtua siswa. Dalam merencanakan dan mempersiapkan pembelajaran, sebagian responden menentukan materi pembelajaran, melakukananalisis materi pelajaran, dan mendiskusikan permasalahan yang dihadapi dalam mengajar bersama dengan kolega. Disamping itu, dalam mewujudkan pertukaran ide dan strategi mengajar hanya sebagian kecil guru yang menyatakan memerlukan umpan balik terhadap pengajarannya di kelas dan memberi masukan kepada kolega yang meminta bantuan terkait strategi mengajar di kelas. guru merasa perlu untuk mengembangkan profesionalisme.

\section{SIMPULAN}

Pembelajaran yang berlangsung di sekolah mempunyai tujuan utama meraih prestasi belajar siswa yang maksimal. Ditinjau dari empat ranah yang menjadi dasar penelitian dapat diketahui bahwa guru telah melaksanakan sebagian besar aktivitas elemen-elemen yang terdapat pada keempat ranah. Untuk langkah perbaikan dalam pembelajaran selanjutnya, informasi mengenai kelemahan-kelemahan dapat menuntun guru mengenali aspek-aspek yang perlu diperbaiki. Adapun kelemahan guru bahasa Arab di MAN III Rawasari Jakarta Pusat adalah: (1) Inovasi pembelajaran terutama pada guru yang sudah senior kurang optimal, dan perhatian terhadap perbedaan karakteristik masing-masing siswa masih belum maksimal; (2) Perencanaan dan persiapan pembelajaran: penyusunan rencana pembelajaran dilaksanakan satu tahun sekali dalam bentuk workshop dan pembekalan 
pengetahuan atau keterampilan tidak didasarkan pada kebutuhan guru melainkan pada program yang dicanangkan oleh dinas pendidikan daerah, belum ada mekanisme memeriksa kebenaran isi dari rencana pembelajaran dan rencana pembelajaran disusun secara individual; (3) Refleksi: mekanisme supervisi yang semestinya dilakukan oleh kepala sekolah dan pengawas masih berada pada taraf pemenuhan administrasi dan belum menyentuh proses pembelajaran yang berlangsung di dalam kelas sehingga guru tidak mendapatkan umpan balik terhadap pembelajarannya di dalam kelas baik dari pimpinan sekolah, teman sejawat atau pengawas; (4) Kolegialitas dan profesionalisme: penyelenggaraan pendidikan dan latihan (Diklat), workshop, dan seminar olehsekolah atau dinas pendidikan terkait masih belum menyentuh kebutuhan guru yang riil di kelas, belum optimalnya proses pendampingan terhadap guru-guru baru, atau guru yang kurang kompeten.

\section{DAFTAR PUSTAKA}

Arikunto, Suharsimi, DasarDasarEvaluasiPendidikan, (Jakarta: BumiAksara, 1995)

Danielson, C. 2011. The framework for teaching evaluation to enchace professional practice. Alexandria, VA: Association for Supervision and Curriculum Development (ASCD).

Djemari Mardapi. 2008. Teknik Penyusunan Instrumen Tes dan Non Tes. Yogyakarta: mitra Cendikia Press.
Freddano, M. \& Siri, A. 2012. Teacher training for school self-evaluation. Procedia - Social and Behavioral Sciences 69, 1142 - 1149.

Gillham, B. 2004. Developing a questionare. London: Continuum.

Johnson, B. \& Christensen, L. 2012. Educational research. Quantitative, qualitative, and mixed approaches. Thousand Oaks, CA: Sage Publication, Inc.

Lavrakas, P. J. 2012. Encyclopedia of survey research methods: Questionnaire. London: Sage Publication.

Marxano, R.J., Frontier, T. \& Livingston, D. 2011. Effectice supervision. Supporting the art and science of teaching. Alexandria, VA: ASCD.

Menpan. 2009. Peraturan Menteri Negara Pendayagunaan Aparatur Negara dan Reformasi Birokrasi (Permennegpan \& RB) Nomor 16 Tahun 2009, tentang Jabatan Fungsional Guru dan Angka Kreditnya.

Miller, D. C. 1977. Handbook of research design and social measurement. New York, NY: David McKay Company, Inc.

Nurgiyantoro, Burhan, PenilaiandalamPengajaranBahasadan Sastra, (Yogyakarta: BPFEYogyakarta, 1987), cetpertama 